\title{
The Right of Access to Information \\ on the Public Administration Activities \\ in Russia and Germany: the Constitutional \\ and Legislative Framework
}

\author{
Elena V. Gritsenko*, Ekaterina G. Babelyuk \\ and Maria I. Proskuryakova \\ St. Petersburg State University \\ 7-9 University Embankment, St. Petersburg, 199034, Russia
}

Received 27.12.2015, received in revised form 18.02.2016, accepted 22.06.2016

The article deals with the constitutional and legislative grounds for the right of access to information in the sphere of public governance in Russia and Germany from a comparative perspective, its content and restrictions are subject to consideration. The thesis that the interpretation of the given right in national legal systems is significantly affected by international and supranational legal regulation is substantiated. However, the degree of such regulation penetration in Russia is rather lower than in Germany. The right of access to information in the public governance sphere is suggested having a dual nature - the right guaranteeing freedom for the individual (status negativus), and the right to participate in the state affairs governing (status activus). Such an approach to the nature of the right of access to information in the public governance understanding offers grounds to a broader understanding of a citizen's information aspiration, where aspiration satisfaction does not depend on the fact whether the requested information affects the citizen's rights or not.

A comparative analysis of the constitutional guarantees of the right of access to information indicates that under the Russian Constitution they are represented more widely in comparison with the German Fundamental Law guaranteeing everyone free information recipience only from sources accessible to public. In this respect, access to information in the sphere of public governance regarding its intraadministrative official nature turned out to be outside the constitutional guarantees framework. At the same time, legislative and enforcing interpretation of the right in question guarantees in Germany tends to their continuous broadening while in Russia both legislative and judicial practice neither complement nor expand constitutional guarantees but concretize them in terms of setting restrictions on the right of access to information. Comparison of the right restrictions both in Russian and German legislation authenticates legal determinacy deficiency of the Russian legislative approach. Moreover, Russian approach in relation to adoption and judicial interpretation of the restrictions of the right of access to information concerning public administration activities is notable for unilateralism which is expressed in the absolutization of the idea of the protection of any restricted access information. In this respect, the use of the German experience in application of a weighing interests' method to conflicts resolution between the right of access to information and other constitutional rights deserves special attention aimed at improving Russian legislation and judicial practice in the sphere under consideration.

(C) Siberian Federal University. All rights reserved

* Corresponding author E-mail address: gricenko.e@jurfak.spb.ru 
Keywords: right of access to information on the public administration activities, the principle of openness and transparence (transparency) of the public authority, protection of restricted access information, a weighing interests ' method.

DOI: 10.17516/1997-1370-2016-9-9-2202-2222.

Research area: law.

\section{Introduction}

Public administration ${ }^{1}$ and public governance modern requirements are no longer confined to the tasks of the service state implementation called to organise efficient and effective public services rendering to the population. Proper and efficient public governance (good governance) implies such an organisation of interrelations between public administration and a citizen on the basis of law under which a man and a citizen acts not as an object of administrative activities but a participator of authoritative processes. Accordingly, the public governance is carried out on the principles of the administration cooperation with the civil society structures. Consistent implementation of the principles of a democratic state and sovereignty of the people requires it as well.

The condition for the authority's viability, efficiency and effectiveness is involvement of citizens and their associations as civil society institutions in its implementation, influence of the public institutions on the authoritative decision making, public control over the authority' activities in general and in the public administration in particular and first of all, in the spheres of public finance use and public property, the choice of the way of public service rendering.

Meeting the challenges of economic development, the choice of the most effective ways to their solution, together with the private actors involvement as well as in the framework of publicprivate partnership projects implementation can be successful only when a certain draft and proposed options for its solutions can be estimated by a neutral party or by independent experts and when the decision-making procedures are carried out under clear and stable rules. All of this in turn is a prerequisite for successful social, economic, investment and innovation policy.

However, it is inconceivable to achieve these goals without the necessary level of information transparency, i.e., public administration transparency ${ }^{2}$ towards the society, where a special role to provide it belongs to the right of access to information in the public governance sphere.

The right in question is relatively new for the Russian legal system ${ }^{3}$. The Soviet period of the Russian statehood was characterized by the confidentiality of information regime concerning the activities of the governing bodies, the closedness of the party and the state apparatus mechanisms of power ${ }^{4}$. Turn for the principle of information openness became feasible owing to the Declaration of the rights and freedoms of man and citizen adoption in 1991, and raising the right to information, the right to participate in the state affairs governing, the right to appeal to the level of constitutional rights being implemented in a democratic and under the rule of law state according to the Constitution of the Russian Federation of 1993.

Subsequently, the given rights and guarantees of their implementation were normatively secured in the sector specific legislation.

Currently, a gradual formation of the national doctrine of information rights in the sphere of public authority and public governance and their framework is taking place. This is significantly 
promoted by the current challenges of the global information society connected with infocommunications revolution, active introduction and use of information and communication technologies (ICT), the change of the very concept of information as an object of legal regulation ${ }^{5}$.

The domestic doctrine of the information rights focuses on the disclosure of the nature and content of the access right to information on the public governance activities, ways to protect the given right, its placement in the system of other subjective rights and correlations with them ${ }^{6}$.

As noted above, it is stipulated by the special significance of the given right in the information society in relations of citizens with the public administration, implementing daily, operative and constant execution of laws and, therefore, interacting with citizens in the most active and close manner as well as in the course of implementation of various administrative procedures and organization of public services rendering. However, certain issues related to the right of access to information in public governance sphere have failed to become a subject matter of scientific discussion in Russian literature so far. For example, the issue of priority between the right of access to information and the right to personal data protection when information on the state organ or local authority activities containing personal data is requested is beyond the modern research. Under such circumstances, research on the right of access to information on public administration activities in a comparative law perspective is of absolute interest and enables us to compare national and foreign experience of regulation, to reveal problem points both of normative enshrinement and practical implementation of the right of access to relevant information in Russia and to propose options to their solutions as well.

The given article suggests the German experience to enshrine and provide the right of access to information in the sphere of public governance. The choice of the German approach to the legal regulation of the right of access to information on the public administration activities as the subject of comparative analysis accounts not only for the proximity of the Russian and the German legal systems, the federal structure of both countries, but for the fact that the regime of confidentiality has long been typical both to the Russian and German traditions of handling with information in the administrative sphere?

The article consists of two sections. The first one is devoted to the constitutional grounds and limits of the right of access to information on the public administration activities in Russia and Germany (Section I). Section II will analyse the legislative framework of the right in question within the legal systems of both countries namely its content (2.1) and restrictions (2.2) will be disclosed.

\section{Constitutional Grounds and Limits of the Right of Access to Information on the Activities of the Public Administration in Russia and Germany}

The right of access to information on the public administration activities is an element of the complex right to information on the one hand, and subjectively legal reflection of objectively legal principle of transparency of public authority - on the other hand. Both of these aspects of access to information have international, supranational and national dimensions ${ }^{8}$.

Accordingly, international and supranational standards of public authority openness accepted by the national constitutional law affect the national constitutional framework of the right of access to information on the public administration activities. The idea of transparency has been firmly established in international environmental law. It was set forth in the Convention of the 
United Nations Economic Commission for Europe "On Access to Information, Public Participation in Decision-making and Access to Justice in Environment related Matters" (Aarhus Convention) in $1998^{9}$. The Convention has the status of a regional international legal treaty directly applicable in the Member States ${ }^{10}$ with its own supervisory mechanism (the Compliance Committee of the Aarhus Convention). Under the Convention the states agreed that their administrative bodies furnish information on the environment condition on the transparency basis. Moreover, such information is deemed to be available to the public in the form of electronic databases via electronic means of communication (paragraphs 2 and 3 of Article 5). Thus, the basis for the formation of the relevant information register on the Internet is created.

Lately, international legal regulation of access to information in the sphere of governance and transparency of public administration has resulted in the further development owing to the implementation of the human rights enshrined in Article 19 of the Universal Declaration of Human Rights, Articles 6, 8 and 10 of the European Convention on Protection of Human Rights and Fundamental Freedoms (ECHR) as well. Thus, in 2008, the Council of Europe Convention on Access to Official Documents was open for signature (14 Member States of the Council of Europe signed the Convention, seven out of 14 ratified it by $2015)^{11}$, and in June 2013 the Charter of Open Data (G8-Open-Data-Charta) ${ }^{12}$ an advisory document of the international conference providing the States with the guidance to carry out the policy of openness was adopted at the "Group of Eight" (G8) summit in Lough Erne.

However, the degree of implementation of these standards in diverse supranational and national constitutional jurisdictions differs seriously. For example, the Russian Federation, in contrast to Germany and the European Union, has not signed the Aarhus Convention yet, although accession to the Convention has been planned since $2012^{13}$. Neither Russia nor Germany have accessed to the Convention on Access to Official Documents yet (as of 2015). As for the Charter of Open Data, the Russian Federation Governmental Commission for coordination of open government activities approved of an action plan on the implementation of the Charter in the Russian Federation as far back as October $2013^{14}$. In Germany, the Ministry of Internal Affairs prepared an Action Plan of the Federal Government to implement the five key principles of the Charter of Open Data by the end of $2015^{15}$.

In this context it is possible to state that the penetration of international standards of openness and transparency in the sphere of public governance into EU law, as well as the national law of the Member States is deeper in comparison with the Russian Federation law. In turn, EU law as well constitutes a serious legal basis for the development of national legislation on the transparency of public administration. Thus, paragraph 3 of article 15 of the Treaty on the Functioning of the European Union (TFEU) under the "primary" EU law per se establishes the right of every European Union citizen to access to documents of the bodies, institutions and other structures and services of the EU, irrespective of the form and data medium used to preserve and transmit such documents. The procedure and the details of this right implementation are stipulated by the act of "secondary" EU law, by the socalled Regulation on transparency. ${ }^{16}$. Moreover, the right of access to information in the sphere of governance is reflected in such an act of "primary" EU law, as the Charter of Fundamental Rights: according to article 41 of the Charter the right of access to documents is an element of the right to proper (good) governance.

Secondary EU law in terms of the regulation of the citizens' right to information and 
transparency in the sphere of public authority together with the Regulation on transparency is represented by a number of acts: EU Directive on the free access to information on the environment 90/313 ${ }^{17}$ of 7 June 1990; taken the place of Directive of 1990 and adopted by the Directive on the public access to information on the environment 2003/4/EU ${ }^{18}$ on the basis of Aarhus Convention; Register of open data (Transparenz-Register) of organizations and independent experts engaged in European politics established on the basis of the agreement between the European Parliament and the European Commission of June 23, $2011^{19}$.

As to the law of integrated associations namely the Customs Union and the Common Economic Space with Russia as a member, as well as to the law of the Eurasian Economic Union, the principles of openness and transparency are also enshrined both in respect of Member States and bodies of intergovernmental organizations ${ }^{20}$. However, this legal regulation is still in its embryo condition.

As for the Russian national constitutional law, the right to information is enshrined in parts 4 and 5 of Article 29 of the Russian Federation Constitution and includes a range of information rights of a man and a citizen, namely the right to seek, receive, produce, transmit, and spread information by any legal means. Freedom of mass information adjoins the right to freely spread information. In this context one should agree with L.K. Tereshchenko who emphasises the identification of the right of access to information with the whole system of subjects' rights to information to be erroneous ${ }^{21}$.

The right of everyone to have access to information can be deduced from the right to freely legally receive information produced, transmitted or spread by lawful means, as well as from the requirement addressed to publiclyauthoritative subject to make everyone aware of the regulatory legal acts affecting the rights, freedoms and duties of a man and a citizen (part 3 of Article 15 of the Russian Federation Constitution); to provide the opportunity for a person concerned to familiarise with the documents and materials directly affecting their rights and freedoms (part 2 of Article 24 of the Russian Federation Constitution), from the right of everyone to trustworthy information about the state of the environment (Article 42 of the Russian Federation Constitution). At the same time the right of access to information on the public administration activities has apart from Article 29 of the Constitution of the Russian Federation additional constitutional basis expressed in the right to participate in governing of the state affairs (Article 32 of the Constitution of the Russian Federation) and is an element, as well as the condition of the implementation of the political right in question.

Thus, the constitutional grounds and guarantee of access to information on the public administration activities can be found in a number of norms of the Constitution of the Russian Federation. Accordingly, a number of questions arise concerning the correlation of these constitutional guarantees between themselves and the limits of the right of access to information on the public administration activities guaranteed by the Constitution of the Russian Federation. Does it cover the possibility for a person concerned to receive any information or only the information that affects their rights and freedoms?

Part 4 of Article 29 of the Constitution of the Russian Federation is deemed to be considered a basic rule governing the right to information in general and the right of access to information in particular, and the constitutional guarantees of information claims set out in part 3 of Article 15, part 2 of Article 24, Article 42 of the Constitution of the Russian Federation - an additional guarantees which, however, do not diminish the content of the right of access to information ${ }^{22}$. Moreover, the 
dual nature of the right of access to information on the activities of the public administration as both the information right (rights - freedoms, status negativus) and the political one (the right to participate in governance, status activus) gives grounds for broader understanding of a citizen's information claims. Accordingly, systemic interpretation of the provisions of the Constitution of the Russian Federation allows to ascertain that the right of access to information on the activities of the public administration is not limited exclusively by that information which directly affects the rights and freedoms of the subject of the given right.

However, the right of access to information on the activities of the public administration being relative may collide with other constitutional rights and freedoms in the course of its implementation. Accordingly, the constitutional guarantees of these rights (protection of private life, secrecy of communication, inviolability of the home and personal data protection attributed to it, the right to free entrepreneurial activities, the right of ownership, including copyright) as well as the restrictions stipulated by the need to protect the public interest form the limits of the right of access to information. Some of them receive a special constitutional enshrinement, such as the requirement of the state secret regime observance concerning the information subject to this regime under the law, and removal of the relevant information out of civilian control specified by Part 4 of Article 29 of the Constitution of the Russian Federation. Thus, the establishment of any restrictions falls within the general requirements, principles and criteria of the rights restrictions set forth in Part 3 of Article 55 of the Constitution of the Russian Federation.

Theconstitutionalgroundsforcommunicative fundamental rights and access to information in the FRG Fundamental Law (hereinafter the Fundamental Law, FL) are presented with significant reservations. According to paragraph 1 of Article 5 of FL, everyone is guaranteed the right to freely receive information only from publicly available sources. Based on a literal interpretation of the given constitutional provision supported by the Federal Constitutional Court of Germany (hereinafter - the German FCC) as a matter of principle, condition for the realization of freedom of information ${ }^{23}$ in terms of claims to access it is establishment of a publicly accessible source and placement information in $\mathrm{it}^{24}$. As noted in the report on the overall assessment of the Federation Law on Freedom of Information 2005 (Informationsfreiheitsgesetz - IFG, hereinafter - the Freedom of Information Act) ${ }^{25}$, according to the prevailing opinion the norm of paragraph 1 (sentence 1) of Article 5 of FL does not contain a requirement appealed to the State and obliging the latter to provide unconditional access to information ${ }^{26}$. Thus, the constitutional guarantees of the right of access to information in the sphere of public governance based on a literal interpretation of the constitutional provisions may cover merely information recognized publicly accessible by the state.

At the same time the issue which information is subject to publicly accessible regime is quite controversial both in the doctrine and in court practice. The evolution of the German FCC positions concerning the guarantees of the right of access to information in the sphere of public governance is noteworthy in this regard. In the Judgement of January 30, 1986, case 1 BvR 1352/85 the Court pointed out that the constitutional guarantees do not affect the acts of administrative bodies, which due to their nature are not usually open, unless the purpose of the act issue provides otherwise in each certain case $^{27}$. However, subsequently, the German FCC slightly displaced the focus to the reasoning of the greater openness in the state bodies' activities, admitting if there are 
constitutional grounds for greater information accessibility provision then such access should be provided to the subject of the fundamental right to freedom of information ${ }^{28}$. The changing of the approach was largely caused by part 1 of Article 10 of the ECHR and paragraph 1 of Article 11 of the European Charter of Fundamental Rights not restraining the right of access to information from dependence on the will of the state and on the creation of a publicly accessible information source. Accordingly, a standpoint that concerning information subject to state authorities disposal operates a subjective, constitutionally protected right of access to information derived from the constitutional principles of the law-governed state and democracy, assuming citizens' participation in the state will formation has spread in the German legislation, legal literature and court practice ${ }^{29}$. Thus, the narrowness of the constitutional guarantees of the right of access to information in the sphere of public governance was overcome by their consistent expansion within current legislation (Freedom of Information Act) and interpretation by the constitutional courts.

At the same time the right of access to information is not infinite. In accordance with paragraph 2 of Article 5 of the Fundamental Law the right to freedom of information, as well as to freedom of expression can be restricted by the general laws' prescriptions, the legislative provisions on the protection of the youth and the right ensuring personal honor protection.

Moreover, the ambiguity of the constitutional interpretation of the freedom of information limits is predetermined among other things by the constitutional recognition of the restriction of access and protection of information, the dissemination of which can unlawfully restrict the freedom of choice of occupation (Article 12 of FL) and right of ownership (Article 14 of FL) (professional and trade secret) or inviolability of private life (Paragraph 1 of Article 2 of FL), as well as infringe the prevailing interests of the common good. All of these points indicate the need to harmonize various constitutional values in solving the issue on the right of access to information limits in practice.

\section{Legislative Framework}

of the Right of Access to Information

on the Activities of the Public

Administration in Russia and Germany

\subsection{The content of the right of access \\ to information on the activities \\ of the public administration}

In the Russian Federation relations connected with ensuring access to information on the activities of the public administration are regulated by the Federal Law of February 9, 2009 № 8-FZ “On Ensuring Access to Information on the Activities of State Bodies and Local Authorities" (hereinafter - the Law on Access to Information) ${ }^{30}$ together with the basic federal law within the information sphere Federal law of July 27, 2006 № 149-FZ “On Information, Informational Technologies and Information Protection" (hereinafter - the Law on Information) $)^{31}$.

Access to information is deemed to be "the ability to receive information and to use it" (paragraph 6 of Article 2 of the Law on Information). It should be noted that literature points out the groundlessness of the lawmaker to expand the notion "access" by means of inclusion the power to use information into $\mathrm{it}^{32}$. Conception of access to information as a category combining two powers - search and recipience is considered more correct ${ }^{33}$.

In accordance with the Law on access to information the subjects which are obliged to 
provide access to information on their activities are as follows:

- state bodies, their territorial bodies, local authorities;

- lower organizations (that is, founded / established by a public entity - unitary enterprises, institutions, public corporations, public funds).

However, the law does not include other organizations vested with public functions into the range of bound persons on the public entity party and by this means involved in public functions performing and public services rendering ${ }^{34}$. Such an exception does not seem consistent with the principle of transparency in the sphere of public governance.

Russian concept of arrangement of the state and municipal services rendering implies participation not only state and municipal bodies and organisations but other authorized entities in this process (Articles 1, 2, etc. of the Federal Law of July 27, 2010 № 210-FZ “On the Arrangement of the State and Municipal Services Rendering" further the Law on Services ${ }^{35}$ ). At the same time the law extends the principle of transparency application to the activities of all subjects involved in the organization of public services rendering (paragraph 4 of Article 4), pointing out the applicants' right "to receive full, timely and credible information on the provision of public and municipal services in electronic form as well" (paragraph 2 of Article 5 of the Law on Services). In this regard, it is logical to assume that the public services providers' obligation to disclose information on their activities in connection with the public services rendering to consumers must be vested with these subjects. It should be noted that the obligation in question also affects the requirements compliance connected with the electronic way of furnishing information as well.

In light of the aforesaid the provisions of the Law on access to information in terms of the range of subjects obliged to disclose information on their activities appear to need adjustment and synchronization with the relevant provisions of the Act on services.

When identifying whether the information refers to information on the state or local authorities' activities the legislator refuses to compile an exhaustive list. In accordance with paragraph 1 of Article 1 of the Law on Access to Information this information concerns:

- information (including documented one) established by the above mentioned state and municipal subjects together with the lower organizations within their tasks;

- information received by the given bodies and organizations;

- enactments establishing the structure, tasks, the order of formation and activities of these authorities and organizations;

- other information concerning their activities.

The given regulatory provisions seem to offer opportunities to a broad interpretation of the "information on the activities of the state and local authorities' activities" concept. However, it must be stated that there is a tendency to a restrictive interpretation of this concept in law enforcement practice. For example, courts of general jurisdiction have confirmed a conclusion that the information on the cost of repairs in the house, where a citizen resides and where the territorial authority of the federal executive body acted as a customer is not referred to the information on the state body's activities; the Constitutional Court of the Russian Federation in which the citizen filed a complaint failed to find any uncertainty in Paragraph 1 of Article 1 of the Law on Access to Information and failed to elucidate why a restrictive interpretation of information on the state bodies' activities is correct $^{36}$.

The issue on whether the applicants have the right of access to any information on the 
mentioned above bodies' activities or only to that one that affects their rights and freedoms is also of great significance in disclosing the right of access to information on the state and municipal bodies' activities content.

According to paragraphs 2 and 3 of Article 8 of the Law on information, applicants are entitled to receive information affecting their rights and freedoms from the state and municipal authorities. Provisions that would establish the fact of the rights and freedoms 'being affected' as a condition for access to information on the state and municipal authorities' activities are wanting in the Law on access to information.

Due to the fact that the said Laws have different objects of regulation one should distinguish between the concepts set forth in them as well as their substantive content: paragraphs 2 and 3 of Article 8 of the Law on information says nothing about "information on the activities of the state and municipal authorities" within the meaning of the Law on access to information but does it only in that part which affects the rights and freedoms of a particular applicant.

Taking into account stated above together with the dual nature of the right on access to information on the public administration activities as an element of the right to participate in the state affairs governing it seems to be reasonable not to make an applicant's possession or lack of possession of this right dependable on the fact whether his rights and freedoms are affected by the requested information.

In Germany everyone's right of access to information on the activities of the federal administrative bodies was laid down in the aforementioned federal Freedom of Information Act 2005. However, characteristics of the individual right in question prove to be quite revolutionary for the German tradition of administrative information concealment - (1) everyone (2) - irrespective of the administrative proceedings carried out against him or with his participation (3) without reasoning his interest in the information and without establishing any substantive prerequisites for the right to request whether legal or based on law interest has the right to access (4) by receiving a reference, familiarizing with the materials or otherwise as well as by sending him copies of documents by post or receiving information via e-mail (5) in respect of any administrative information, (6) except for the information provision of which is inadmissible under the law ${ }^{37}$.

Freedom of Information Act gave impetus to the federal Lands legislation to develop in the indicated direction. Moreover, laws of the Lands on citizens' access to information on the activities of the administrative authorities of the direct and indirect Land governance in a number of cases went further by establishing not only the public administration obligation to provide information at the request of the person but enshrining its extensive obligations on ensuring an open access to information in the sphere of public administration by means of its publication on the Internet in accordance with the list stipulated by the Act (Transparenzregister). Hamburg Act on transparency (Hamburger Transparenzgesetz) ${ }^{38}$ which scope goes beyond typical law of the Land on freedom of information as it regulates both administration' obligations to provide information at the request and limits of the publicly accessible information and the order of such public access provision is noteworthy in this regard.

In this connection one can encounter opinions about a tendency of "a turn from freedom of information legislation in its traditional sense to transparent legislation" in Germany ${ }^{39}$.

It can be stated that at present the doctrine and judicial practice of Germany develop in both aforementioned directions: 1) implementation of the right of access to information upon request; 2) implementation of the public administration 
obligation to systematize the information subject to disclosure, and to arrange public access provision to it.

In connection with the legislation on freedom of information application in Germany special attention is paid to the interpretation of the following key elements of the right of access to information in the sphere of public governance upon request: 1) the circle of the right of request subjects; 2) the circle of the request addressees (a wide interpretation of the "administrative body" and "institutions executing public administrative functions" as well as the administrative functions themselves and administrative activities); 3) the circle of information sources falling within the notion of information in the administrative sphere, and especially 4) exceptions assuming possibility or obligatoriness of refusal to give access to information $^{40}$ - absolute and relative grounds for refusal to give access to information ${ }^{41}$.

\subsection{Restrictions on the right of access}

to information on the activities

of the public administration

Article 4 of the Russian law on access to information enshrined the principle of openness and accessibility of information on the activities of government bodies and local authorities as the basic principle provided a number of exceptions from this principle.

Just as in the Law on Information, information constituting the state or another secret protected by the law (part 1 of Article 5 of the Law on Access to Information) is referred to the number of restricted access information. It is noteworthy that the explanatory note to the bill refers only to the official secret ${ }^{42}$ along with state secret among other secrets protected by the law. Refusal of specifying other secrets falling within article 5 of the Law in the text of the explanatory note gives rise to certain surprise. The enumeration of the secrets protected by the law in the explanatory note could have allowed to more clearly delineate the scope of the restriction of the right of access to information; the inclusion of the provisions reasoning the absolute ban on access to information referred to any secret protected by the law in the explanatory note might have allowed to understand the legislator's objectives in establishing legal regulation in question.

Article 5 of the Law on Access to Information contains a mandatory rule stipulating that the list of information and the conditions of information reference to the secret protected by the law should be established by the federal law. If the Russian Federation Law "On State Secret" July 21, 1993 № 5485-1 is passed and operates in respect of information constituting a state secret then the issue on reference of information to the category of official secret has not been legislatively resolved up to the present time yet. Thus, the provision of Article 5 of the Law on access to information (as well as the provision of part 4 of Article 9 of the Law on Information) remains unimplemented.

The authors of one of the commentaries to the Law on information suggest considering an official secret as "secondary" one derivative of other secrets: if the information constituting any other secret protected by the law has been revealed in the course of official tasks implementation it is converted into an official secret status ${ }^{44}$. However, such a narrow interpretation of an official secret - official information of limited access is confirmed by neither normative, nor law enforcing practice.

Conditions of information reference to the official secret are regulated by the Presidential Decree "On Approving the List of Confidential Information” of March 6, 1997 № 188 (amended in 2005) $)^{45}$. Paragraph 3 of the List defines official information as a kind of confidential one, if the access to it is restricted by the relevant public authorities in accordance with the Civil Code 
and Federal laws. At the same time, "an official secret" is not the subject of civil legislation regulation.

One gets the impression that the organs of state power and local self-government, without clear guidelines on referring information to the official one are entitled to interpret freely enough the most general framework established by the laws on information and on access to information in determining the circle of official information of restricted access.

In addition, the Regulation on the procedure for handling official information of restricted access in the federal executive authorities and in the authorized governing body of the nuclear energy use approved by the RF Government Decision № 1233 of 3 November, 1994 (amended in 2012 $)^{46}$ operates on the federal level. At the same time, indication to the legislative norms pursuant to which it is passed is wanting in the text of the given Decision. The criteria for the information reference to the official one of restricted access and its dissemination is defined much wider in the normative act in question "official necessity", for all that the given criterion is not construed.

The procedure for referring information to the official one on the level of the RF subjects and municipalities has not been defined at the federal level at all.

In respect of personal data also being restricted access information (except for those contained in the publicly accessible sources), the Law on Access to Information contains a provision stating that it does not cover the relations connected with the access to such data. As consequence, the relations of the processing of personal data contained in the information on the state bodies and local authorities' activities are subject to the Federal Law "On Personal Data" (hereinafter - the Law on Personal Data) application $^{47}$.
Any reservations providing the peculiarities of the Law on personal data application to these legal relations are wanting in the Law on access to information.

Differently directed interests underlying the right of access to information on the state bodies and local authorities' activities (information disclosure) and the right to personal data protection (keeping information secret), predetermine contentious nature of the given rights relationship in cases where the scope of one right overlapping the scope of another one. Respective "overlapping" takes place when an information user tries to get access to information on the state bodies and local authorities' activities containing personal data.

The current legislative regulation does not allow to go beyond the assertion that all personal data contained in the requested information must be kept confidential provided that there is no consent of the subject of personal data and none of the statutory events of personal data processing in the absence of such consent has occurred. At the same time, such a legislative approach seems not to take into account the peculiarities of the legal relations connected with the provision of information on state bodies and local authorities' activities, and supports an additional argument in favor of refusal to give access to information. In addition, there are doubts as to the validity from a constitutional point of view concerning the absolute priority of the right of personal data protection over the right of access to information.

In general, the approach chosen by the Russian legislator to defining the access to information restrictions on the public administration' activities is characterized by establishing common reservations providing for an absolute prohibition on the restricted access information provision. At the same time the law maker does not provide the list of grounds for 
refusal of access to information. Such a legislative approach results in:

- absolutisation of the task to protect the secrecy and security of the regime of access to relevant information restriction;

- exclusion of the possibility of "weighing" differently directed interests in connection with the fact that there are no events on the occurrence of which provision of the restricted access information could be acceptable (for example, in the event of the predominance of interest in information disclosure over the interest in its concealment $)^{48}$.

Moreover, in practice along with the above mentioned exceptions and restrictions additional grounds for refusal of providing information based on defined objectives as permissible restrictions of constitutional rights (part 3 of article 55 of the Constitution of the Russian Federation) and outside the connection with the protection of legally protected secrets are widely used. So, not only the reference of the requested information to the secret protected by the law but any other reference of it to restricted access information in accordance with the Law on information, including the fact of affecting the rights and legitimate interests of other persons ${ }^{49}$ works as the ground for the refusal to provide information requested by the Law on access to information. The given ground for access to information restriction is supported by judicial practice as well. According to the Russian Federation Constitutional Court Ruling of February 7, 2013 № 134-O access to information may be restricted or prohibited even if the information is not subject to secret protected by the law but affects the rights, freedoms and interests of other persons and is referred to the restricted access information as prescribed by the federal law ${ }^{50}$.

The courts of general jurisdiction while considering citizens' applications concerning their right of access to information in the sphere of public governance violation, and justifying the refusal to satisfy applicants' claims often refer to the fact that the information requested affects the rights and freedoms of other persons ${ }^{51}$.

The German lawmaker implemented an approach different from the Russian one in terms of the regulation of restrictions on access to information on the public administration activities. The Freedom of Information Act defines exceptions from the principle of information accessibility as detailed as possible and lays them down in $\S \S 3-6: \S 3$ in order to protect particular public interests (Schutz von besonderen öffentlichen Belangen) establishes events when a claim for access to information does not exist; $\S 4$ provides protection to departmental decision-making process (Schutz des behördlichen Entscheidungsprozesses); § 5 - to personal data (Schutz personenbezogener Daten); $\S 6$ - to intellectual property and trade secret (Schutz des geistigen Eigentums und von Betriebs - und Geschäftsgeheimnissen). Laws defining peculiarities of access to certain types of information (e. g. Act on Information on the Environment (UIG) ${ }^{52}$, Act on Improving Consumers' Awareness on the State of Health Information $(\mathrm{VIG})^{53}$ ) are passed and operate in Germany along with the Freedom of Information Act having a fundamental nature. Relevant special laws contain their own grounds for refusal of access to information, which sometimes differ significantly from the provisions of $\S \S 3-6$ of Freedom of Information Act. Restrictions on access to information established by a special law will be subject to application. Paragraph 3 of $\S 1$ of the Freedom of Information Act results in a given conclusion according to which the rules on access to information on the activities of the public administration contained in other legislative enactments have a priority meaning except for $\S 29$ of the Law on Administrative Procedures (Verwaltungsverfahrensgesetz - 
$\mathrm{VwVfG}$ ) and $\S 25$ of book 10 of the Social Code (Sozialgesetzbuch - SGB).

A parallel between the Russian Law on access to information seems possible to draw in the part where the Freedom of Information Act sets the priority of special regulation. According to part 2 of Article 2 of the Law, if the federal constitutional laws, federal laws together with other normative legal acts of the Russian Federation passed in accordance with them set forth peculiarities of certain types of information provision on the state bodies and local authorities' activities, provisions of the Law on access to information are applied with regard to the peculiarities stipulated by the relevant regulatory acts. However, in contrast to the German Freedom of Information Act, the Russian Law admits of the possibility of establishing "peculiarities" of information provision including the by-laws level (as the case is with information relating to official secret in particular). Taking into account the fact that the "peculiarities" can also be a ground for refusal of access to information, danger of restricting the right of access to information by a by-law arises.

The provisions of the German Freedom of Information Act set forth the restrictions of access to information on the activities of the public administration, are different depending on whether:

- they establish an absolute ban on access to information $(\S 3, \S 4, \S 6)$, or contain a reservation on weighing (Abwägungsklausel) and allow to provide a restricted access information upon the occurrence of conditions stipulated by the law ( $\$ 5$ );

- they restrict access to information in order to protect public interests ( $\$ \S 3$ and 4 ) or private interests ( $§ 55$ and 6$)$.

$\S 3$ of the Freedom of Information Act, which as far back as the legislative process caused heated debate ${ }^{54}$ establishes more than 30 sets of exceptions (depending on the way to count) ${ }^{55}$ from the principle of openness and accessibility of information on the activities of the public administration. According to $\S 3$ of the given Act the claim of access to information does not exist, for example, in the following cases:

- if the disclosure of information can have negative consequences for international relations (item 1a), the interests of internal and external security (item 1c), control and supervisory tasks of financial authorities, competition control bodies, regulatory organs (item 1d);

- if the information disclosure is likely to endanger public safety (item 2);

- if and until the necessary confidentiality of international negotiations (item 3a) or intraadministrative consultations of the public administration bodies are damaged (item $3 b$ );

- if the information disclosure could harm the fiscal interests of the federation in the course of economic turnover or economic interests of the social insurance (item 6);

- if the obligation to keep secret or confidentiality or the information is subject to protection as a professional secret or a special official secret is established by the statutory regulation (Rechtsvorschrift) or general administrative regulation (Allgemeine Verwaltungsvorschrift) on material and organizational protection of classified materials (Verschlusssachen) (item 4) ${ }^{56}$;

- in respect of the intelligence services, as well as public administration bodies and other federal public authorities and organizations to the extent they carry out the tasks provided by item 3 of $\S 10$ of the Security Clearance Check Act $(\mathrm{SÜG})^{57}$ (item 8).

Grounds for refusal to provide information, as set forth in $\S 3$ of the Freedom of Information Act are the exceptions from the principle of free access to information on the public administration activities, they must be understood narrowly ${ }^{58}$ and always construed in the light of the transparency principle $^{59}$. 
As the analysis of $\S 3$ of the Freedom of Information Act shows, the grounds for refusal to grant access to information on the activities of the public administration are formulated not in an abstract way, but specifically with the maximum specification and enumeration. On the one hand, this approach fails to avoid overlapping of the different grounds for refusal of access to information from the content point of view ${ }^{60}$. In this regard, the fact that several grounds for refusal of access to information under $\S 3$ of the Act are of significant importance in almost all trials, as the authors of the commentary to the Freedom of Information Act emphasize is quite explainable ${ }^{61}$. On the other hand, the advantage of such an extensional nature of $\S 3$ lies in the fact that the very text of the Act itself takes accounts of different interests by different ways and in this respect the application of the Act by the citizens wishing to get access to information facilitates ${ }^{62}$.

$\S 5$ of the Freedom of Information Act defines the peculiarities of access to personal data contained in the information on the activities of the public administration. The paragraph in question indicates that the legislator follows the way of differentiated regulation of relations connected with access to personal data contained in the information on the public administration' activities. $\S 5$ of the Act norms in aggregate allow to speak that according to the general rule the protection of personal data is given "based on principle" $" 63$ though "relative priority" $" 64$ in relation to the right of access to information. However, the legislator does not only exclude the possibility of situations where an interest in receiving information will be of more significance but enshrines two examples of such situations in paragraphs 3 and $4, \S 5$ of the Act either.

Appeal to the German experience in the sphere of regulation of access to information on the public administration' activities containing personal data demonstrates unilateralism of the approach to regulation of these relations selected by a domestic legislator even more clearly. The absolute priority of the right to protection of personal data laid down in the Law on access to information on the state bodies and local authorities' activities could have been reviewed in order to establish a more balanced regulation allowing to provide for a balance between the right of access to information on the activities of public administration and the right to personal data protection. The corresponding revision can consist of introducing amendments to the Law on access to information that would identify peculiarities of providing access to personal data contained in information on the activities of the state bodies and local authorities. Such a provision could establish different from the provisions of the Law on personal data rules of access to them without the consent of the personal data subject. Moreover, it is necessary to further define the events where the personal data may also be provided.

\section{Conclusion}

Comparison of the Russian and German approaches to enshrining, guaranteeing and restricting the right of access to information on the activities of the public administration enables not only to identify common features and peculiarities of each of them, but to assess the domestic experience critically either.

Despite the fact that the right of access to information in the sphere of public governance in the very text of the German Fundamental Law is interpreted very narrowly - only public information from a publicly accessible source in the Federal Freedom of Information Act, and partly in the FCC practice, the given fundamental right gets a broader interpretation. The right to receive information under the Constitution of the Russian Federation is presented wider than in the German Fundamental Law without any 
special reservation. Accordingly, legislative concretization and judicial interpretation of the said right are aimed not at the expansion of constitutional guarantees but at the establishment of mechanisms for its implementation, limits and restrictions. Both legal systems recognize the dual nature of the right of access to information in the sphere of public administration - both as a manifestation of personal freedom to receive information, and as a means of implementing the principle of a democratic state - participation in governing its affairs, which implies openness and transparency of public administration as well. In this connection, affectedness of rights and freedoms is not regarded as a condition of access to such information. However, it does not mean that access to information is ensured without any restrictions. Presence of both constitutional and legislative restrictions of access to information is common to both states.

Peculiarities of the Russian and German legal basis for access to information on the activities of the public administration is largely predetermined by the different level of implementation of international legal standards of access to information and openness of public administration in the national legal systems of Russia and Germany, as well as by differences in perception and development of these standards in the European Union law and in the law of the integration associations with the Russian Federation participation.

Peculiarities of the Russian approach to the interpretation of the right of access to information in the sphere public governance restrictions are in the absolutization of the task to protect the secrets and observe the prohibition of access to information, which is subject to the regime of restricted access under the law. At the same time the legislator often does with very general wordings and reservations, leaving wide space for the definition of restricted information on the by-law level (e.g. official information) or using the common reference to the legitimate objectives specified in part 3 of Article 55 of the Constitution of the Russian Federation (as for example affectedness of the rights and legitimate interests of other persons). As a result, in the event of conflict of the right of access to information with other rights (such as the right to personal data protection) the law enforcement body does not conduct any weighing of the protected values giving unconditional priority to the protection of information. At the same time the judicial review of the availability of sufficient grounds and observance of the necessary criteria for the information to be subject to the regime of restricted access is not carried out either.

German experience in the implementation of constitutional guarantees and restrictions on the right of access to information in the sphere of public governance offers rich material for a deeper and comprehensive approach to the resolution of the above mentioned conflicts not only for the improvement of Russian legislation but for the judicial practice in this area.

\footnotetext{
Under the public administration here and further is deemed the executive authorities, and other administrative bodies, local governments, and other entities vested with public-legal status and fulfilling administrative functions, including public services rendering. What is at issue is the aggregate of administrative bodies of public legal entity as an institutional reflection of the public governance. Being introduced in Western and international law legal lexicon, the term "public administration" gradually enters into the Russian legal terminology. (More: Gritsenko, E. European doctrine of proper public governance, and prospects of its realisation in the Russian law (Comparative Constitutional Review. 2013 . №2. pp.115-128. P.116).

2 The issue on the principles of openness and transparency of public governance correlation is controversial. Without going into details of this discussion, it should be noted, however, that in accordance with the Concept of openness of federal executive bodies, approved by Order of the RF Government on January 30, 2015 №93-p (http://www.pravo.gov.ru , 02.03.2014), the openness of these bodies is represented by the aggregate of principles - the principle of information trans-
} 
parency, the principle of clarity, the principle of civil society involvement in governance, the principle of accountability (Sec. III of the Concept). As for the principle of transparency, it is commonly regarded as an element of the principle of openness and comes to information transparency. See: Nesterov, A.V. On the standard (concept) of the openness of «open government» (Preprint - January, 2014) Available at: http://pravo.hse.ru/expertika/news/109952852.htm, (accessed: 18 August 2015).

3 In contrast, for example, with the Swedish legal system, where the access to the official information of the public administration, subject to certain exceptions observance has been introduced to everybody irrespective of their specific legal interest since 1776. See: Griebel, T. Die verfahrensrechtliche Absicherung von Informationsfreiheitsrechten in rechtsvergleichender Sicht. Eine Betrachtung der Rechtslage in Schweden, den USA, Deutschland und der Europäischen Union. 2007, Duncker \& Humblot. S.29; Schoch, F., IFG-Kommentar. 2009, München Beck. Rn.29.

4 See e.g. Abrosimov I. HR authority policy in the USSR 1939-1953. Part2. The phenomenon of the Soviet nomenklatura. Available at: http://www.proza.ru/2011/03/20/1140, (accessed: 18 August 2015).

5 See more: Talimonchik V.P. International legal regulation of relations in the sphere of information: Abstract of dissertation for the degree of doctor of legal sciences. Saint Petersburg, 2013. P.13.

6 See e.g. Pavlov I.Y. Legal provision of the access to official information. Abstract of dissertation for the degree of candidate of legal sciences. Moscow, 2008; The right of access to public information as a condition of transparency development of the state: round table discussion of the XI International conference on economic and social development, State university - Higher School of Economics, 2010 (Law. 2010. № 4); Tereshchenko L.K. The legal regime of information. Abstract of dissertation for the degree of doctor of legal sciences. Moscow, 2011.

7 The starting point for the handling of information in the administrative sphere in Germany is the principle of confidentiality of public governance, based on the so-called hiding information tradition (Arkantradition). See: Wendt, Ph. Abschied vom Amtsgeheimnis, Anwaltsblatt, 2005. P. 702; details: Wegener, BW Der geheime Staat: Arkantradition und Informationsfreiheitsrecht, Morango, Göttingen, 2006. Cit.: Boyml A. Transparency of PPP projects from the point of view of German law (Public-private partnerships in the municipal sector). Moscow: Infotropik Media 2013.

8 See e.g. Article 19 of the International Covenant «On Civil and Political Rights» of 1966, Article 10 of the Convention for the Protection of Human Rights and Fundamental Freedoms of 1950. According to the organization «Transparency International Russia», «currently about a hundred states have separate laws on the right to information”. Cit.: Bratanovskii S.N., Lapin S.Y. The right of access to information as an element of the constitutional right to information. (Citizen and Law. 2012. № 8. p. 23).

9 The text of the Aarhus Convention: Available at: http://www.un.org/ru/documents/decl_conv/conventions/orhus. shtml\#mainnav (accessed: 18 August 2015).

10 The Convention was signed by - 40 future Parties - 39 States and the European Union by 21 December 1998 - the date of completion of the signature period. After that Convention was open for other States accession. See about this: the Aarhus Convention. Implementation Guide. UNECE:http:/www.unece.org/fileadmin/DAM/env/pp/implementation\%20guide/ russian/aigr.pdf (accessed: 18 August 2015).

11 The text of the Convention (CETS №205) and a table of ratifications see on Council of Europe website: http://conventions. coe.int/Treaty/rus/Summaries/Html/205.htm (accessed: 18 August 2015).

12 The official text of the Charter and the Technical Annex thereto, see: https://www.gov.uk/government/publications/opendata-charter/g8-open-data-charter-and-technical-annex (accessed: 18 August 2015).

13 Paragraph 22 «a» of the Action Plan for the implementation of the Fundamentals of the state policy in the field of environmental development of the Russian Federation up to 2030 approved by the Russian Federation Government Order on December 18, 2012 № 2423-p (Collection of Legislation of the Russian Federation). 2012. № 52. Art. 7561.

14 See materials on the web site of the Expert Center of the e-government: http://d-russia.ru/pravitelstvennaya-komissiyautverdila-plan-realizacii-xartii-otkrytyx-dannyx.html (accessed: 18 August 2015).

15 Nationaler Aktionsplan der Bundesregierung zur Umsetzung der Open-Data-Charta der G8 (http://www.bmi.bund.de/ SharedDocs/Downloads/DE/Broschueren/2014/aktionsplan-open-data.pdf?_blob=publicationFile) (accessed: 18 August 2015).

16 Regulation (EC) No 1049/2001 of the European Parliament and of the Council of 30 May 2001 regarding public access to European Parliament, Council and Commission documents (OJ 2001 L 145/43).

17 Council Directive 90/313/EEC of 7 June 1990 on the freedom of access to information on the enviroment (OJ 1990 L 158/56.)

18 Directive 2003/4/EC of the European Parliament and of the Council of 28 January 2003 on public access to environmental information and repealing Council Directive 90/313/EEC (OJ 2003 L 41/26).

19 Agreement between the European Parliament and the European Commission on the establishment of a transparency register for organisations and self-employed individuals engaged in the EU policy-making and policy implementation (OJ 2011 L 191/29.).

20 See e.g. Acts of primary law: «The agreement on trade in services and investment in the member states of the Common Economic Space» (concluded in Moscow 09.12.2010, ratified by Federal Law of 11.07.2011 N 181-FL) (Collection of Legislation of the Russian Federation. 2012. N 4. Art. 453); acts of secondary law: The Decision of the Board of Eurasian Economic Commission of 05.03.2013 N 31 «On ensuring transparency in the adoption of acts of the Eurasian Economic Commission in the application of sanitary, quarantine, phytosanitary and veterinary-sanitary measures» (posted on the official website of the Eurasian Economic Commission http: //www.eurasiancommission.org/ - 14.08.2013); Article 69, and others of Treaty on the Eurasian Economic Union, signed in Astana 05.29.2014, the official portal of legal information http://www.pravo.gov.ru, 16.01.2015.

21 Tereshchenko L.K. Op. cit. by: Bachilo I.L. Information law: the textbook for the Masters. Moscow, Iurait, 2013. P. 230. 
22 Compare: Pavlov I.Y. considers «the fundamental constitutional regulator of the right of access to information [on the state and local authorities' activities] provisions ...of P. 4 Art. 29 of the Constitution of the Russian Federation. Provisions of P. 2 Art. 24 of the Constitution of the Russian Federation grant additional guarantees of this right in respect of that official information which directly affects the rights and freedoms of the persons concerned" (Pavlov I.Y. Op. cit. P. 8).

23 It should be noted that in German literature, as well as in legal documents the term «freedom of information» (Informationsfreiheit) is used to indicate the right of everyone to have access to information on the activities of the public administration. A. Roßnagel being very critical to this states that «freedom of information itself is a too big word for an individual right of the general and unconditional access to the acts of the public governance» (Roßnagel A., Konflikte zwischen Informationsfreiheit und Datenschutz? MMR, 2017. S. 16).

24 BVerfG, Beschluss v. 2.9.1994 («Parabolantenne I»), Az. 1 BvR 1687/92, BVerfGE 90, 27 ff., Rn. 13 (juris). See also: Kloepfer, M. / Schärdel, F. Grundrechte für die Informationsgesellschaft - Datenschutz und Informationszugangsfreiheit ins Grundgesetz? JuristenZeitung 2009, Heft 9. S. 459; Bröhmer, J. Transparenz als Verfassungsprinzip: Grundsatz und Europäische Union, 2004, Mohr Siebeck. S. 224 f.

25 Gesetz zur Regelung des Zugangs zu Informationen des Bundes (Informationsfreiheitsgesetz) v. 5.9.2005 in d. F. v. 7.8.2013 // BGBL. I S. 2722; BGBL. I S. 3154.

26 See: Ziekow, J., Debus, A., Musch, E. Abschlussbericht „Evaluation des Gesetzes zur Regelung des Zugangs zu Informationen des Bundes - Informationsfreiheitsgesetz des Bundes (IFG) - im Auftrag des Innenausschusses des Deutschen Bundestages“, 22. Mai 2012. S. 52. This final report is the result of research conducted by the German research Institute for public governance in Speyer city on the instructions of the Committee on internal affairs (Innenausschuss) of Bundestag. The text of the report is available online at: https://www.transparency.de/fileadmin/pdfs/Themen/Verwaltung/Informatio nsfreiheit /174522BEvaluationIFGGutachten.pdf (accessed: 18 August 2015)

27 BVerfG, Urteil v. 31.01.1986, Az. 1 BvR 1352/85, NJW 1986, 1243 (juris).

28 BVerfG, Urteil v. 24.1.2001, Az. 1 BvR 2623/95, 1 BvR 622/99, BVerfGE 103, 44 ff., Rn. 59 (juris).

29 See: Scherzberg, A. Von den arcana imperii zur freedom of information - Der lange Weg zur Öffentlichkeit der Verwaltung, Thüringer Verwaltungsblätter. 2003, S. 200 f.

30 Federal Law of February 9, 2009 № 8-FZ «On Ensuring Access to Information on the state bodies and local authorities’ activities» with further amendments (Collection of Legislation of the Russian Federation. 2009. № 7. Art. 776).

31 Federal Law of July 27, 2006 № 149-FL «On Information, Information Technologies and Protection of Information» with further amendments (Collection of Legislation of the Russian Federation. 2006. № 31 (ch. 1). Art. 3448).

32 See: Mindrova E. A., Collision of citizens' right of access to information and the right to inviolability of private life in the information society. Abstract of dissertation for the degree of candidate of legal sciences. Moscow, 2007, pp. 16-17.

33 Compare: Bachilo I.L. Op.cit. P. 153.

34 For comparison: the addressee of the application in part 1 of Article 1 of the Federal Law of May 2, 2006 № 59-FZ «On the order of consideration of the Russian Federation citizens' applications» has a wider definition. It includes other authorized entities carrying out publicly important functions.

35 Federal Law of July 27, 2010 № 210-FZ «On the organization of the state and municipal services rendering» with further amendments (Collection of Legislation of the Russian Federation. 2010. № 31. Art. 4179).

36 See: The Ruling of the Constitutional Court of the Russian Federation of December 8, 2011 № 1624-O-O On the complaints of the citizens: Andreeva Tatyana A., Morozov Philippe V. and others about violation of their constitutional rights by paragraph 1 of Article 1 of the Federal Law "On Ensuring Access to Information on the of State Bodies and Local Authorities Activities" (the document has not been published. Available at: http://doc.ksrf.ru/decision/KSRFDecision82617. pdf (accessed: 18 August 2015).

37 In addition to the general legislation on freedom of information in Germany together with other countries specific legislation on access to information in some very important areas - the state of the environment in particular (Umweltinformationsgesetz) and to the information in the consumer sector (legislation on consumers' information rights (Verbraucherinformationsgesetz) has been developing as well.

38 Hamburgisches Transparenz Gesetz v. 19.6.2012 // HmbGVBL. I, 2012. S. 271.

39 Eisenmenger, S. Kammer und Transparenz - zugleich ein Beitrag zu den internationalen, unionalen und nationalen Konturen des Transparenzrechts, in: Kammern in einem sich wandelnden Umfeld / Hrsg.vHEberhard, UEZellenberg, Wien: Sramek, 2014. S.136-152.

40 See: the generalization with further references: Schoch, F. Aktuelle Entwicklungen im Informationsfreiheitsrecht nach dem IFG des Bundes, Neue Zeitschrift für Verwaltungsrecht, 2013, $1033 \mathrm{ff}$.

41 The comparative analysis of these versatile enough grounds for the restriction of the right of access to information in the sphere of the public governance in relation to the Russian experience is given below (see paragraph 2.2).

42 The text of the explanatory notes to the bill № 386525-4 "On providing access to information on the state bodies and local authorities' activities": http://asozd.duma.gov.ru/main.nsf/(Spravka)?OpenAgent\&RN=386525-4 (accessed: 18 August 2015).

43 Law of the Russian Federation of July 21, 1993 № 5485-1 "On State Secret” with further amendments (Collection of Legislation of the Russian Federation. 1997. № 41. Art. 8220-8235).

44 Kovaleva, N.N., Cholodnaia E.B. Commentary to the Federal Law of 27 July 2006 N 149-FZ "On Information, Information Technologies and Protection of Information" (itemized) (Reference System Consultant Plus. 2007).

45 Presidential Decree of March 6, 1997 № 188 «On Approval of the List of Confidential Information» with further amendments (Collection of Legislation of the Russian Federation. 1997. № 10. Art. 1127).

46 Government Decision of November 3, 1994 № 1233 «On approval of the Regulation on the Handling of Official Information of Limited Distribution in the Federal Bodies of Executive Power, and the Authorized Governing Authority of the 
Nuclear Energy Use,» with further amendments (Collection of Legislation of the Russian Federation. 2005. № 30. P. II. Art. 3165).

47 Federal Law of July 27, 2006 № 152-FZ «On Personal Data» (Collection of Legislation of the Russian Federation. 2006. № 31 (Part 1). Art. 3451).

48 In this regard, it is important to pay attention to the alternative experience proposed in the Convention on Access to Official Documents open for signature but has not come into effect yet. The Convention also contains provisions on the legitimacy of access to official documents restriction that must be proportional to the protection objectives itemised in Article 3, but part 2 of Article 3 contains a very important reservation - despite the restrictions, the information may be disclosed «if there is a predominant public interest in its disclosure». It can be said that the Convention provisions allow to digress from the formalistic approach and enables the competent authority (the court or other independent and impartial bodies) to assess the legitimacy of the refusal.

49 See: Article 5 and 19 of the Law on access to Information in conjunction with Article 9 of the Law on Information.

50 Item 2.3, paragraph 1 of the reasoning part of the Ruling of the Constitutional Court of the Russian Federation of 07.02.2013 $\mathrm{N}$ 134-O «On the complaints of the citizens: Tatyana A. Andreeva and Daniil V. Yurchenko about the violation of their constitutional rights by the provision of Paragraph 2 of Article 5 of the Federal Law «On the procedure of the Russian Federation Citizens' Complaints Consideration» (The Bulletin of the Constitutional Court of the Russian Federation). 2013. №5).

${ }^{51}$ Korenovskii district court of Krasnodar Region decision of 19 February 2014, case № 2-326 / 2014 (available at: http://korenovsk.krd.sudrf.ru/modules.php?name=sud_delo\&srv_num=1\&name_op=case \&case_id=1674636\&delo id=1540005); Determination of the St. Petersburg City Court on 27 January 2011, case № 33-53 / 2011 (available at: http:// sankt-peterburgsky.spb.sudrf.ru/modules.php?name=sud_delo\&srv_num=1\&name_op=doc\&number=2010882\&delo id $=5 \&$ new $=0$ \& text_number $=1 \&$ case_id=633061).

52 Umweltinformationsgesetz (UIG) in der Fassung der Bekanntmachung vom 27. Oktober 2014 // BGB1. I S. 1643.

53 Gesetz zur Verbesserung der gesundheitsbezogenen Verbraucherinformation (Verbraucherinformationsgesetz - VIG) in der Fassung der Bekanntmachung vom 17. Oktober 2012 // BGBl. I S. 2166, 2725.

54 Jastrow, S.-D., Schlatmann, A. Informationsfreiheitsgesetz: Kommentar. R. v. Decker's Verlag, 2006. S. 57.

55 Berger S., Partsch Ch., Roth J., Scheel Ch. Informationsfreiheitsgesetz. Kommentar, 2., neu bearbeitete Auflage. Carl Heymann's Verlag 2013. § 3, Rn. 1.

56 In Germany detailed legislation on the protection of secrets has been formed. For example the laws containing instructions on keeping information secret are as follows: the Law on Protection of the Constitution (BVerfSchG), Code of Criminal Procedure (StPO), the Law on Administrative Offences (OWiG), the Law against Restraints of Competition (GWB), Security Clearance Check Act (SÜG). The General administrative regulation refers to the General Administrative Order of the Ministry of Internal Affairs on the material and organizational protection of classified material on March 31, 2006. This order is taken in pursuance of $\S 35$ SÜG. Taking into account that the obligation of secrecy or confidentiality follows directly from $\S 4$ SÜG, giving the definition of «confidential materials" notion (Verschlußsachen) and establishing four degrees of classified material (top secret, secret, confidential, only for official use), reference to the Order in the text of the Act seems unnecessary. For detail, see: Gesetzentwurf der Fraktionen SPD und Bündnis 90 / die Grünen. Drucksache 15/4493. S. 11, http://dip21.bundestag.de/dip21/btd/15/044/1504493.pdf; Berger S., Partsch Ch., Roth J., Scheel Ch. Informationsfreiheitsgesetz. § 3, Rn. 113, 121-124; Jastrow, S.-D., Schlatmann, A. Informationsfreiheitsgesetz. § 3, Rn. 68-86.

57 Gesetz über die Voraussetzungen und das Verfahren von Sicherheitsüberprüfungen - Sicherheitsüberprüfungsgesetz (SÜG) vom 20. April 1994 // BGB1. I S. 867.

58 Gesetzentwurf. Drucksache 15/4493. S. 9.

59 Berger S., Partsch Ch., Roth J., Scheel Ch. Informationsfreiheitsgesetz. § 3, Rn. 13.

60 Thus, Ch. Schnabel while analysising the judicial practice the Freedom of Information Act application comes to a conclusion that the exception from the principle of the free access to information under item $3 a, \S 3$ is completely covered by item 1a, $\S 3$ in the sense it is construed by the Federal Administrative Court of Germany. See: Schnabel, Ch. Der Schutz öffentlicher Belange vor der Informationsfreiheit, in: Informationsfreiheit und Informationsrecht, Jahrbuch 2011. S. 154.

${ }^{61}$ Berger S., Partsch Ch., Roth J., Scheel Ch. Informationsfreiheitsgesetz. § 3, Rn. 10.

62 Rossi, Informationsfreiheitsgesetz, § 3 Rn. 7. Цит. по: Mecklenburg, W., Pöppelmann, B. Informationsfreiheitsgesetz: Gesetzestexte, Kommentierungen, Fallbeispiele, Erläuterungen. Bonn, DJV, 2007. § 3, Rn. 3.

${ }_{63}$ Schoch, F. Aktuelle Entwicklungen im Informationsfreiheitsrecht nach dem IFG des Bundes. Neue Zeitschrift für Verwaltungsrecht, 2013, 1038.

${ }^{64}$ Ziekow, J., Debus, A., Musch, E. Abschlussbericht „Evaluation des Gesetzes zur Regelung des Zugangs zu Informationen des Bundes - Informationsfreiheitsgesetz des Bundes (IFG) - im Auftrag des Innenausschusses des Deutschen Bundestages". S. 324.

\section{References}

Berger, S., Partsch, Ch., Roth, J., Scheel, Ch. Informationsfreiheitsgesetz. Kommentar, 2., neu bearbeitete Auflage. Carl Heymann's Verlag, 2013.

Bröhmer, J. Transparenz als Verfassungsprinzip: Grundsatz und Europäische Union, Mohr

Siebeck, 2004. 
Eisenmenger, S. Kammer und Transparenz - zugleich ein Beitrag zu den internationalen, unionalen und nationalen Konturen des Transparenzrechts, in: Kammern in einem sich wandelnden Umfeld / Hrsg.v.H.Eberhard, U.E.Zellenberg, Wien: Sramek, 2014. S.136-152.

Griebel, T. Die verfahrensrechtliche Absicherung von Informationsfreiheitsrechten in rechtsvergleichender Sicht. Eine Betrachtung der Rechtslage in Schweden, den USA, Deutschland und der Europäischen Union, Duncker \& Humblot, 2007.

Jastrow, S.-D., Schlatmann, A. Informationsfreiheitsgesetz: Kommentar. R. v. Decker's Verlag, 2006.

Kloepfer, M. / Schärdel, F. Grundrechte für die Informationsgesellschaft - Datenschutz und Informationszugangsfreiheit ins Grundgesetz? In: JuristenZeitung 2009, Heft 9. S. 453-462.

Mecklenburg, W., Pöppelmann, B. Informationsfreiheitsgesetz: Gesetzestexte, Kommentierungen, Fallbeispiele, Erläuterungen. Bonn, DJV, 2007.

Roßnagel A., Konflikte zwischen Informationsfreiheit und Datenschutz? In: Multimedia und Recht 2007, Heft 1. S. 16-21.

Scherzberg, A. Von den arcana imperii zur freedom of information - Der lange Weg zur Öffentlichkeit der Verwaltung, in: Thüringer Verwaltungsblätter. 2003, Heft 9. S. 193-203.

Schnabel, Ch. Der Schutzöffentlicher Belange vor der Informationsfreiheit, in: Informationsfreiheit und Informationsrecht, Jahrbuch 2011. S. 153-178.

Schoch, F. Aktuelle Entwicklungen im Informationsfreiheitsrecht nach dem IFG des Bundes, in: Neue Zeitschrift für Verwaltungsrecht 2013, Heft 16. S. 1033-1040.

Schoch, F., IFG-Kommentar. München: Beck, 2009.

Ziekow, J., Debus, A., Musch, E. Abschlussbericht „Evaluation des Gesetzes zur Regelung des Zugangs zu Informationen des Bundes - Informationsfreiheitsgesetz des Bundes (IFG) - im Auftrag des Innenausschusses des Deutschen Bundestages”, 22. Mai 2012.

Bachilo I.L. Informatsionnoe pravo:uchebnik dlia magistrov [Information Law: the textbook for the Masters]. 3 ed.Moscow: Iurait 2013.

Bratanovskii, S.N.,Lapin, S.I. Pravo na dostup $k$ informatsii kak element konstitutsionnogo prava na informatsiiu [The right of access to information as an element of the constitutional right to information](Citizen and Law. 2012. № 8). pp. 35-44.

Kovaleva, N.N., Cholodnaia E.B. Kommentarii k Federal'nomu zakonu ot 27 iiulia 2006 goda $N$ 149-FZ [Commentary to the Federal Law of 27 July 2006 N 149-FZ "On Information, Information Technologies and Protection of Information” (itemized) (Reference System Consultant Plus). 2007.

Mindrova E. A. Kolliziya prava grazhdan na dostup k informatsii i prava na neprikosnovennost' chastnoi zhizni $v$ usloviiakh informatsionnogo obshchestva. [Collision of citizens' right of access to information and the right to inviolability of private life in the information society]. Abstract of dissertation for the degree of candidate of legal sciences. Moscow, 2007. Pavlov I.Y. Pravovoe obespechenie dostupa k ofitsial'noi informatsii . [Legal provision of the access to official information]. Abstract of dissertation for the degree of candidate of legal sciences. Moscow, 2008.

Pravo na dostup $k$ publichnoi informatsii kak uslovie razvitiia transparentnosti gosudarstva: materiali kruglogo stola XI Mezhdunarodnoi nauchnoi konferentsii po problemam razvitiia ekonomiki $i$ obshchestva [The right of access to public information as a condition of the state transperancy: round 
table material of the $9^{\text {th }}$ International scientific conference on economic and social development] State University -Higher School of Economics, 2010 (Law 2010. № 4). pp. 145-156.

Tereshchenko, L. K. Pravovoi rezhim informatsii [The legal regime of information] Abstract of dissertation for the degree of doctor of legal sciences. Moscow, 2011.

\title{
Право на доступ к информации
}

\section{о деятельности публичной администрации \\ в России и Германии: конституционные \\ и законодательные пределы}

\author{
Е.В. Гриценко, Е.Г. Бабелюк, \\ М.И. Проскурякова \\ Санкт-Петербургский государственный университет \\ Россия, 199034, Санкт-Петербург, \\ Университетская набережная, 7-9
}

\begin{abstract}
В статье в сравнительном аспекте анализируются конституционные и законодательные основания права на доступ к информации в сфере публичного управления в России и Германии, раскрываются его содержание и ограничения. Обосновывается тезис о том, что на интерпретацию указанного права в начиональных правопорядках существенное влияние оказывает международное и наднациональное правовое регулирование, при этом степень проникновения такого регулирования в России несколько ниже, чем в Германии. Право на доступ к информации в сфере публичного управления предлагается рассматривать как имеющее двойственную природу - право, гарантирующее свободу личности (status negativus), и право на участие в управлении делами государства (status activus). Такой подход к пониманию природы права на доступ к информаџии в сфере публичного управления дает основания для более широкого понимания информачионных притязаний гражданина, не ставя их удовлетворение в зависимость от того, затрагиваются ли запрашиваемой информацией права гражданина или нет.

Сравнительный анализ конституиионных гарантий права на доступ к информации показывает, что в российской Конституции они представлены шире по сравнению с немецким Основным законом, гарантирующим каждому беспрепятственное получение информации только из общедоступных источников. В связи с этим доступ к информации в сфере публичного управления, учитыввая ее внутриадминистративный, служебный характер, оказался за рамками конституционных гарантий. В то же время законодательная и правоприменительная интерпретация гарантий рассматриваемого права в Германии идет в сторону их постоянного расширения, тогда как в России и законодательная, и судебная практика не дополняют и не расширяют конституционные гарантии, а конкретизируют их в части установления ограничений права на доступ к информации. Сравнение ограничений рассматриваемого права в законодательстве России и Германии свидетельствует о наличии дефицита правовой определенности российского законодательного подхода. Более того, российский подход в части установления и судебной интерпретации ограничений права на доступ к информации о деятельности публичной администрации отличается односторонностью, которая выражается в абсолютизации идеи защиты любой информации ограниченного доступа. В связи с этим использование немецикого опыта применения метода взвешивания интересов при разрешении конфликтов между правом на доступ к
\end{abstract}


информации и иными конституцчионными правами заслуживает особого внимания в изелях совершенствования российского законодательства и судебной практики в рассматриваемой сфере.

Ключевые слова: право на доступ к информации о деятельности публичной администрации, принцип открытости и прозрачности (транспарентности) публичной власти, защита информации ограниченного доступа, метод взвешивания интересов.

Научная специильность: 12.00.00 - юридические науки. 